\title{
Article \\ Usological Turn in Archiving, Curating and Educating: The Case of Arte Útil
}

\author{
Alessandra Saviotti ${ }^{1, *(1)}$ and Gemma Medina Estupiñán ${ }^{2}$ (I) \\ 1 School of Art and Design, Liverpool John Moores University, Liverpool L3 5UX, UK \\ 2 Faculty of Humanities, Universidad de la Laguna, 38200 San Cristobal de la Laguna, Spain; \\ gemma.medina@gmail.com \\ * Correspondence: a.saviotti@2019.ljmu.ac.uk
}

check for updates

Citation: Saviotti, Alessandra, and Gemma Medina Estupiñán. 2022. Usological Turn in Archiving, Curating and Educating: The Case of Arte Útil. Arts 11: 22. https:// doi.org/10.3390/arts11010022

Academic Editors: Andy Abbott and Elaine Speight

Received: 14 December 2021

Accepted: 19 January 2022

Published: 21 January 2022

Publisher's Note: MDPI stays neutral with regard to jurisdictional claims in published maps and institutional affiliations.

Copyright: (C) 2022 by the authors. Licensee MDPI, Basel, Switzerland. This article is an open access article distributed under the terms and conditions of the Creative Commons Attribution (CC BY) license (https:// creativecommons.org/licenses/by/ $4.0 /)$.

\begin{abstract}
Since its inception in 2013, the Arte Útil archive has become a collective steadily expanding as a tool for research and a resource for social practitioners. The archive is available for consultation at the website and consists of a growing database of around three hundred case studies that use art as a tool for societal change. It provides artistic strategies, a historical perspective, and a nexus between theory and praxis, besides being a platform to connect artistic projects and "users" from different geographies and contexts. Overall, it has become a nomadic pedagogical device able to trigger the discussion and the analysis of socially engaged art practice, its nature and its context involving not just artists but social agents and communities. As co-curators of the archive and educators, we interrogated ourselves regarding if curating as a social practice could expand the notion of education. Could we embrace the methodology of social practice to curate and generate pedagogical conditions fostering sustainability? Could we go beyond the conventional spaces and dynamics of academia? Could we integrate concepts like co-authorship and co-curating to cross from the arts to collective learning environments? How do we relate with the archive in other local contexts? In the last five years, we have implemented an evolving methodology that addresses all these questions, activating the Arte Útil archive as a pedagogical catalyst. The archive allowed collective experimentation and became a tool to infiltrate social practice both in the academic domain and galleries and museums' educational ecosystems. In this article, we will analyse two different examples as case studies: from a research and artistic environment, a conversation with Onur Y1ldız and Naz Kocadere, co-authors of "Art in use: case studies in Turkey" in May 2018, from a two-day workshop organised in collaboration with the Office of Useful Art at SALT Galata, Istanbul (TR); and from an educational perspective, the recent curriculum developed as part of the International Master Artists Educator (iMAE) in ArtEZ, Armhen (NL).
\end{abstract}

Keywords: usological turn; Arte Útil; critical pedagogy; durational practice

\section{Introduction}

The Arte Útil archive was the result of a year and a half of research that started in 2012 in the context of the exhibition The Museum of Arte Util (2013-2014), presented at the Van Abbemuseum in Eindhoven (NL) by artist Tania Bruguera. The composition of the archive was carried on through a curatorial research-led process by Bruguera in collaboration with the curatorial teams at the Queens Museum in New York (USA), the Van Abbemuseum, Grizedale Arts in Coniston (UK), an international group of correspondents ${ }^{1}$, designers and architects collective ConstructLab, an open call, and, eventually, composed by independent researchers Alessandra Saviotti and Gemma Medina Estupiñán. The archive presents a growing number of case studies from 1827 until today, that imagine, create, and implement beneficial outcomes, by advancing tactics that change users' behaviour not only with respect to approaching art, but also in their everyday life. 
The definition of Arte Util is entangled with the conception of the criteria ${ }^{2}$ used to gather the case studies, and the writing process behind them was led by the research itself. To be included in the Arte Útil archive, a project should:

1. Propose new uses for art within society

2. Use artistic thinking to challenge the field within which it operates

3. Respond to current urgencies

4. Operate on a 1:1 scale (Wright 2013)

5. Replace authors with initiators and spectators with users

6. Have practical, beneficial outcomes for its users

7. Pursue sustainability

8. Re-establish aesthetics as a system of transformation

The necessity to define a set of principles was essential in the first instance to create a collective understanding of what Arte Útil means and to be able to share that idea with an extended group of curators, artists, students, constituencies, and users. Secondly, the criteria were pivotal in scoping the research about which case studies to include, and to demonstrate how they could function as guidelines for other researchers working in those organizations willing to engage with the archive. Lastly, they helped those who were involved in the first phase of the project to make the selection process as transparent as possible. Through the criteria, the research that constituted the archive allowed the extended curatorial team to understand the research process differently. Consciously moving from the exhibition device to the realm of usership, archiving became a radical way of producing knowledge that questioned concepts such as universal evidence and the supposed neutrality of the researcher and the institution (Rito and Balaskas 2020).

In practical terms, the case studies are organised on a website (www.arte-util.org, accessed on 2 December 2021) by categories such as urban development, scientific, pedagogical, politics, economy, environment, and social, which identify the fields within which artists decided to transform their proposal from speculative to operational, or art on a 1:1 scale (Wright 2013). According to Wright, art practices that manifest on a 1:1 scale do not use any object or surrogate to situate themselves into the world. The definition suggests how in this case art refuses any device to represent what it is manifesting itself as a work in real life that goes beyond its interpretation as an artwork. Wright continues:

"They are not scaled-down models—or artworld-assisted prototypes—of potentially useful things or services (the kinds of tasks and devices that might well be useful if ever they were wrested from the neutering frames of artistic autonomy and allowed traction in the real). Though 1:1 scale initiatives make use of representation in any number of ways, they are not themselves representations of anything. The usological turn in creative practice over the past two decades or so has brought with it increasing numbers of such full-scale practices, coterminous with whatever they happen to be grappling. 1:1 practices are both what they are, and propositions of what they are". (Wright 2013)

Ultimately case studies are recorded and organised through what are called 'cards' that are available as downloadable and printable documents (Figure 1). The cards function as an index where users can read some basic information such as who initiated the project, a description, where it is located, the goals, its beneficial outcomes, how it is maintained and funded, who uses it, and, finally, some useful links and other media such as videos (available on the digital version).

At the outset, the archive has been the centre of the enunciation of a theory of use applied to art, and it outlasted the relatively short time span of the exhibition, becoming in and of itself a meta-artwork, or an art-work-as-para-institution ${ }^{3}$. In fact, the structure where the cards are displayed, the cards, and the way of interacting with all the elements constituting it - whatever it might be-can be adapted to every space according to the needs. The initial intention behind the conception of the archive was to support the research around Arte Útil as a way to exceed the reiteration of inherited epistemologies. At the time 
of this writing, the archive has become a tool to access information on projects and a way to make the research process public; a repository of interviews, texts, and reports that are the result of constituencies' and students' interaction with it; and, finally, a network of artists and activists who might employ the same strategies and tactics more of less manifestly on a 1:1 scale.

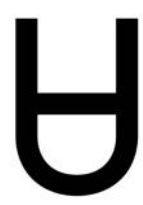

Arte Útil archive nr:

580

Initiator:

Fabrizio Urettini

Location:

Italy

Category:

economy, social

Users:

Asylum seekers, refugees,

migrants, desigers, fashion

Treviso.

\section{Maintained by:}

The project is completely self-

sustainable thanks to the

products' sales. Operating as a

circular economy, it collaborates

in particular with Lanificio

Paoletti, a local textile factory

which provides fine fabric for the

fashion produce. Sales make 500

to 700 EUR average: part of the

money gets reinvested in materials

for the workshop, part is used

purchase food for collective

need to send money back home

need to send money back home

for emergencies. Recently the

Vitra Design Foundation (under

the supervision of the Swiss

uthorities), which purpose is to

promote the awarness for art,

design and architecture.

Duration:

2016 - ongoing

\section{Fabrizio Urettini}

Talking Hands

Description:

The project responds to the urgency that many asylum seekers and refugees have as soon as they touch a new country's soil: working and learning the language. The project, located in the former army barrack 'Caserma Plave in Treviso, started as rocts sell furniture, clothes and embroidery. Through the organisation of different free workshops in collaboration with local, national and international designers and workshops in collaboration with local, national and international designers and
artisans, the project promotes the professional development of the participants and it creates job opportunities. The products are sold during special events and the profit is partly distributed between the participants and re-invested within the project.

Goals:

Due to the funding cuts operated by the government to the welcoming and protection system for refugees and asylum seekers, basic services such as literacy, mental health and individual support have significantly decreased. Through its activities, the project gives professional training, basic literacy as well as social support. The skills of the participants are valued as well through the collaboration with local artisan, national and international designers in supporting the

Beneficial Outcomes:

The core group is composed of 15 people who, in turn, are in charge of the workshops, and around 50 people who hang out in the space every day. Besides professional training the project gives legal and healthcare support, and it provides free communal meals and some money for those in need.

Images:
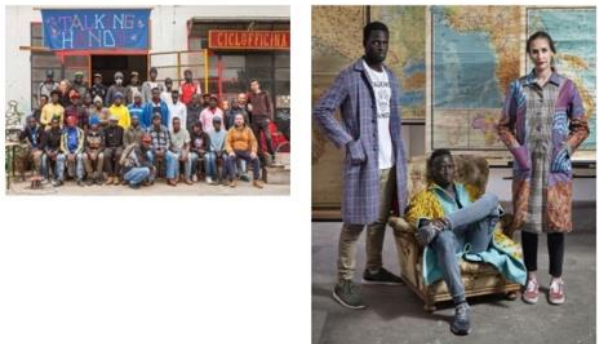

Figure 1. Each case study included in the Arte Útil archive is recorded through a form that generates pdfs that are free to download from the website www.arte-util.org.

To conclude this section and to introduce the next, we borrow the words of Shaina Anand (2016), when she affirms that 'the archive is not representational, it is creative, therefore naming something as an archive, is not the end, but the beginning of a debate'.

\section{The Arte Útil Archive beyond the Exhibition: Emancipating Usership}

After the conclusion of the exhibition at the Van Abbemuseum, the Arte Útil archive expanded its own entity beyond the institution's walls as an online repository capable of growing and disseminating organically through usership. Under the umbrella of the Asociación de Arte Útil, it has evolved as a continuous research collective around the uses of art that raises manifold questions and problematises the role of institutions, socially 
engaged art practices, education, and contemporary art embedded in specific contexts. Since the nineteenth century, similar questions had been already formulated by different figures within Western Art History, challenging the prevailing discourse around art and institutions and breaking through the patterns of modernity.

In his article "The museums and the thirsting millions", Arthur C. Danto (1997) reflected on an episode narrated by John Ruskin in 1848 in a letter addressed to his father. While Ruskin was at the Municipal Gallery in Turin, Italy, drawing a female figure inspired by Veronese's "Salomon and the Saba Queen", he unintentionally listened to a sermon by a preacher from the Waldensian Church in the gallery. This juxtaposition of discourse and the painting provoked a transcendental experience, a catalyst that served to "un-convert" him. Danto argued that this event could not be regarded as a "routinary experience" around art, but a transformative encounter, like a reaction to a philosophical thought interpolated in daily life (Danto 1997, pp. 176-78). Notably John Ruskin (1870) championed the need to connect art and life, expanding the pedagogical capacity of art and museums to inspire reflection and learning as fundamental tools to deal with the struggles of everyday life. A century later, amid his theories to reconsider the notion of art declining the traditional concept of aesthetics, Danto demanded institutions of knowledge (museums and the academy) to operate differently, embracing their pedagogical character to foster transformative experiences.

The theory advanced by Danto is similar to that put forward by Alexander Dorner. As a matter of fact, Dorner is considered a forerunner of New Institutionalism ${ }^{4}$ (Doherty 2004) because of his inquiries about the purpose of art and the failure of the conventional museum. In his curatorial practice, essays, and lectures, the art historian required the institution to confront its previous function as a storehouse to become a "powerhouse": a platform for acquiring experience, learning cultural development, and receiving civic training, connecting art with the needs of life. In 1947 he affirmed:

"What we call "art" has actually become the symbol of this separation of life into two worlds: the world of an unchanging spiritual essence and the sensuous world of change-creating forces. The "work of art" has come to represent an ideal static condition, and therefore a self-sufficient and self-enclosed idol that assures man of the eternal victory of that ultimate "form" over all forces of change.

The cure can obviously come only from an inner change in the imagination process itself, where the very act of conceiving is imbued with the aim to help life actively rather than simply to contemplate it passively". (Dorner 1958)

In the past five years, the Arte Útil archive has revisited some of these interrogations founded in a radical departure: usership. Following the so called "usological turn" enunciated by Stephen Wright (2013, p. 65) - intended to denote the rise of practices that welcome use and repurpose of the work of art challenging the usual categories of authorship and spectatorship-usership becomes a site of value emanated from the collective production of knowledge. If it is not used, the Arte Útil archive fails (Medina and Saviotti 2019). Such a usological turn has been actively embraced by diverse groups, artists, organisations, institutions, and individuals who use the archive and, on many levels, activate its potentiality to function as a crowbar to crack open the existent concept of art and its institutional space (Yildiz and Kocadere 2018). As a consequence, the curatorial process becomes a way of collectively archiving and researching that goes beyond exhibition making. As Jean-Paul Martinon and Irit Rogoff argue in "The Curatorial, a Philosophy of Curating", there is a difference between what we consider 'curating' and 'the curatorial':

"If 'curating' is a gamut of professional practices that had to do with setting up exhibitions and other modes of display, then 'the curatorial' operates a very different level: it explores all that takes place on the stage set-up, both intentionally and unintentionally, by the curator and views it as an event of knowledge. So to drive home a distinction between 'curating' and 'the curatorial' means 
to emphasise a shift from the staging of the event to the actual event itself: its enactment, dramatization and performance". (Martinon and Rogoff 2013)

\subsection{Broadcasting the Archive}

One of the first projects which emerged as a consequence of The Museum of Arte Util was Broadcasting the archive as illustrated in Figure 2 (2015-2018). We designed the project in dialogue with the Van Abbemuseum and other institutions that became part of the discussion about the principles of Arte Útil and how to put them into practice. The focus of the project was threefold: we were keen to emancipate usership around the Arte Útil archive through providing information to people organising themselves in their own community; we wanted to expand the research that started with the exhibition; and we were looking forward to learning from some projects we included in the archive. In particular, the project aimed to activate and mediate the archive beyond the museum's context, developing a touring programme of activities, workshops, and discussions hosted by different organisations departing from the Netherlands to Belgium, Spain, the United Kingdom, the United States, and Italy. As a methodological approach, the project actively fostered means of collaboration, co-creation, and dialogue unfolding the program together with organisations and groups of practitioners. General questions, activities, and case studies were linked to local issues and specific urgencies. The programme responded to each context where the archive operated as a catalyst. Our objective was to question the physical and metaphorical walls of the institution through a call for action, disseminating the archive as a source of inspiration both for a specialised public and a non-trained contemporary art audience. Every activity was conceived to be co-designed with users, and it functioned as a pedagogical device for students, curators, artists, researchers, critics, and the general public ${ }^{5}$.

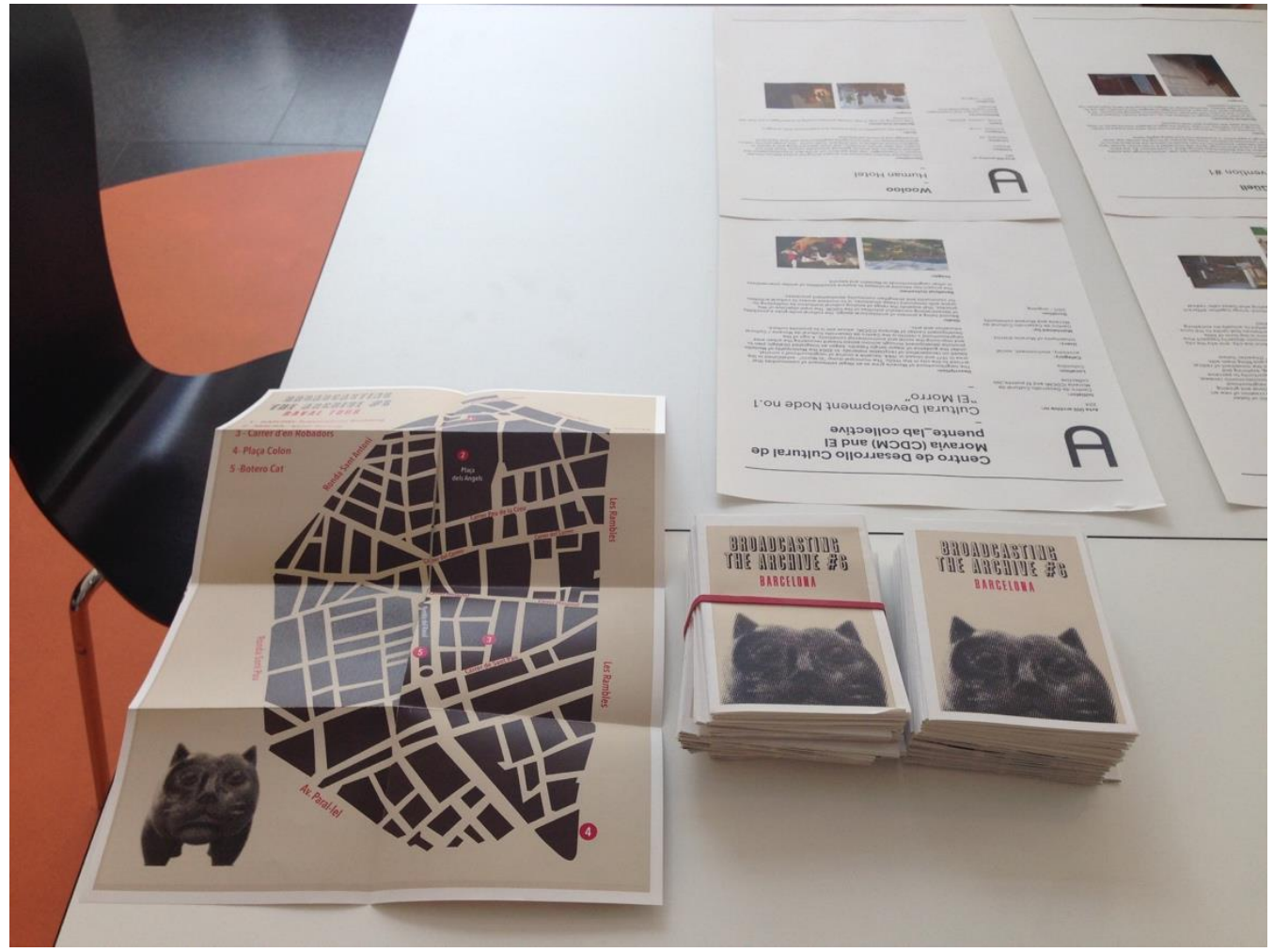

Figure 2. Broadcasting the archive \#6-Barcelona. A two-day programme realised in collaboration with Avalancha and The Umbrella Network at MACBA-Museu d'Art Contemporani de Barcelona (25-26 June 2016). Guests: Núria Güell, Ruben Santiago, Valentina Maini, and BioBui(L)t-Txema. 


\subsection{Agents of Change}

In parallel with the development of the previous project, Agents of Change (2015-2019) was focused on a reconsideration of the significance of an art museum on a local scale. The project was part of the programme Working with constituents by L'internationale, a confederation of European museums ${ }^{6}$ and it was initiated by The Umbrella Network ${ }^{7}$ in collaboration with the Van Abbemuseum and the Eindhoven's Council.

It started from a series of conversations with students of social design at the Design Academy Eindhoven about the possible uses of the archive in the context of their studies. The aim was to expand the research around the intersection between socially engaged art practices, social design and Arte Util in the city. The project activated the archive as the initial tool to inspire and generate a network of local practitioners, mapping community initiatives, social, and creative projects. In total, seventy-three citizens' initiatives were part of the network dealing with a wide range of local urgencies. They included collective kitchen gardens and urban agriculture, beekeepers, community centres, recycling clubs, forest warding volunteers, second-hand stores, open shared libraries, (rejected) refugee's shelters, support and care networks for elderly and kids, time banks, community art projects, public pedagogy initiatives, art and design organisations and residencies, and so on. Most of the groups involved did not have any previous connection with the museum or a clear interest in contemporary art. Essentially, they were intrigued with the idea of describing their initiatives as an artistic project, using the format of the archival cards. Although it opened the possibility of submitting their projects into the archive, they mainly considered it unnecessary. Many groups, in fact, operate entirely independently from any institutional support. However, they valued the fact to have their project represented as archive cards which would become another tool to facilitate the self-analysis in terms of goals, actions and beneficial outcomes. The initiators of Agents of Change co-organised guided tours through the city, visiting the different initiatives, workshops, and activities, linking the groups with the museum's programme. Thanks to the project, a network of local practitioners arose, and this originated multiple collaborations after it concluded. This established the basis for a dialogue between the institution and several communities to reconsider preconceived ideas about the museum's role within society and what art can do. It was fundamentally the initial step for a long-term process inviting other voices into the institution to formulate a shared experience, not as spectators or participants, but as constituencies, able to link contemporary local issues with the narratives around $\mathrm{art}^{8}$.

In the light of these projects, as co-curators of the archive and educators, we asked ourselves if curating as a social practice could expand the notion of education. Following the observations of Carolina Rito and Bill Balakas (Rito and Balaskas 2020, p. 9), in Institution as praxis we interrogated whether and how we could change the way we understand research and knowledge production. Working collectively across different fields, such as museums, galleries, and universities, presented us with a series of questions that we will try to unpack through the analysis of the following projects: Yararl Sanat Ofisi at SALT-Galata in Istanbul, Turkey; and a series of syllabi conceived and delivered at the international Master Artist Educator at the ArtEZ, University of the Arts in Arnhem, The Netherlands. To study the results of the different nature of the encounters between the archive and those who engaged with it, we asked:

- Could we embrace the methodology of social practice to curate and generate pedagogical conditions fostering sustainability ${ }^{9}$ ?

- Could we go beyond the conventional spaces and dynamics of academia?

- Could we integrate concepts like co-authorship and co-curating to cross from the arts to collective learning environments?

- How do we relate with the archive in other local contexts? 


\section{Yararlı Sanat Ofisi at SALT in Istanbul}

What follows is the result of an interview that we conducted in September 2021 with the former public programs' director at SALT Onur Yıldız and curator Naz Kocadere, who were in charge of the Yararl Sanat Ofisi (the Office of Useful Art) at SALT Galata, Istanbul (TR), between 2017 and 2019. The aim of this conversation was to analyse the potential of the archive as an operational curatorial device, which could be adapted to a different context from that which it originated, and at the same time to scrutinise retrospectively what worked in SALT's context and what did not.

The Office developed as a research-led project in dialogue with the Asociación de Arte Útil between September 2017 and December 2019. It was included as part of a trajectory already in place at SALT, which sought to place focus on 'expanding the potential of colearning among the institution and its users' (SALT 2017). The question of how to foster usership was already debated within the institution for it is a research organization based on an archive. However, approaching Arte Útil was used as a new platform for experimenting within commonly created resources with a broad range of people and constituents from other fields other than art, in particular social practices focused on education, the right to the city, censorship, and so on. Furthermore, the Office of Useful Art became a study platform to expand the conversation around usership in art in the context of Turkey, and, at the same time, it developed as the core of an evolving network of researchers and experts that were invited to broaden the archive including case studies from the neighbour countries such as Armenia, Bulgaria, Georgia, and the Middle East.

By its nature, the Arte Útil archive is both an artwork and a tool for research. Therefore, one of the first conceptual and practical challenges was to articulate how a cultural institution delivers its mission through a format different from the exhibition. Consequently, the following question was about understanding how to approach the archive as an exhibition device or tool rather than an artwork. The latter was tentatively resolved through the design of a radio programme called 'Arte Útil Archive' on Açık Radyo hosted by Yıldız and Can Gümüss, which discussed particular case studies with artists and cultural producers based in Istanbul. In this way, the archive became a means by which to connect international projects with practitioners in the city and the region and to get acquainted with the topic.

At the outset, the conversations gravitated towards the different projects that were carried out by artists and other practitioners rather than attempting at unpack the principles of Arte Útil per se. As noted by both Yıldız and Kocadere, the criteria in their case were a limitation: starting from the meaning of 'Util' that in Turkish translates as 'Yararlı' suggesting 'beneficial' rather than 'tool' or 'device' in contrast with the original implication in Spanish, the criteria, rather than being at the centre of the discussion, have remained in the background, and they were never considered neither a constraint nor an entry key for the research. Practitioners who offered their projects to be studied under the lens of Arte Útil questioned the definition in and of itself; Kocadere pointed out that many social initiatives that were considered as potential candidates for the archive arose from either a need or for the sake of use without an artistic ambition. Therefore, they did not feel that it was relevant to label them as 'art'. The key to resolve this issue was to read them as possible alternative public pedagogies. So, approaching Arte Útil as a possible method rather than as a movement ${ }^{10}$ helped to reconcile the institutional need to frame a practice 'as art' with their constituents' practice, which often exceeded or broke out of this frame.

Considering that, the questions that were posed during the many public sessions hosted by the Office were focused on what it would imply for art to be useful in responding to the urgency of the time, in a country where the subject of urgency changes very quickly because, as Kocadere pointed out, 'certain political turmoil really never ends'. As a consequence, the Office became an entry point for institutional self-reflection rather than the space in which to formulate statements about what art should be. For example, it was debated how the programming could change under the lens of usership, or how an institution can involve its constituents in a more pluralistic way. 
Curiously, a similar position was articulated by former Arts Catalyst curator Alec Steadman in 2016, on the occasion of one of the first adaptations of the Office of Useful Art. Steadman, together with the team at Arts Catalyst (London, UK), collaborated with the Asociación de Arte Útil in order to create an active and flexible space that could support-through the archive-their research in the context of 1:1 scale practices at the intersection of art, science, technology and ecology. However, in that case one of the main challenges was to consider how the selection process of case studies to include in the archive could be opened up in a transparent and sustainable way, and how to leave behind the hierarchy in which an international institutional élite-represented by the members of the Asociación-decides what can be considered as Arte Util and what cannot. As he pointed out:

"For an initiative with radical political intent such as Arte Util, it is essential that the form of any selection process live up to the collective ethical imperative of the projects it represents. If Arte Útil wants to fulfil its ambition to represent (or even be) a movement, it must open up decisions about what that movement is to all those it frames within it. I would argue all the initiators and all the users of the projects included within the archive should be included in the process setting the boundaries of inclusion and exclusion for their community. Exactly how this might be achieved is of course a complex problem with no easy solutions. But the opportunity of a para-institution with a focus on such radical forms of practice must be seized to develop new radical institutional processes. Otherwise, the Arte Útil archive is in danger of repeating the same logics of power its contents are actively fighting against". (Steadman 2016)

At SALT, the issue of the decision process was resolved by accepting that the programme would have never been complete without the contribution of independent researchers and attendees. One of the changes that was used to advance this position was the adoption of a 'remunerated usership scheme', where attendees were specifically invited to co-create the public programme and offered book tokens in exchange. This simple adjustment in power dynamics was unexpected and it revealed, in principle, how relatively easily such mechanisms can be reversed, despite the fixed structures of the institution. The experiment resonated in a subsequent programme called 'Researchers at SALT', where independent researchers were invited to publicly present their work and share how they were using the institution's online archive. This process resulted in the creation of a user-lead form of programming parallel to that of the institution.

To conclude, it seems that one of the outcomes of The Office of Useful Art at SALT ${ }^{11}$ was essentially creating the conditions for imagining how a different institution could function, using the tools and tactics that the archive provides. As noted by Asli Seven, who took part in a two-day workshop focused on collectively selecting case studies from Turkey, the archive serves two competing functions. On the one hand, it is a tool for power when it determines what is worth remembering. On the other, it can become a tool for resistance when the experiences of those that are marginalized can be articulated (Seven 2018). What struck us from this experience is the potential for imagination that the archive offers throughout its wide range of practices represented by the case studies. The fact that it operates within an institutional context through a recognizable format, gives room for radical conversations to happen in situations where freedom for engaging in political discourse is very limited, such as in the case of Turkey.

\section{The Collaboration with the International Master Artist Educator at ArtEZ, Arnhem}

The second case study approaches another institution of knowledge: the university. While implementing Broadcasting the archive, we understood the project was evolving into a public pedagogy for it started to gain traction across different schools and academies. Following this trajectory, we tried to apply the principle of Arte Útil as a way to produce and disperse knowledge through a collective process involving the students as our constituency. This took the form of a series of collaborative and flexible syllabi that opened 
the possibility for speculation on the meaning of curatorial research-led practice through both the mediation and the use of the archive. As Irit Rogoff (2008) announced in Turning, the educational approach could be understood as an expansive, generative movement that opens up a new horizon that emerges during the process, leaving behind the praxis that was its initial starting point.

Since 2017, we have led a class on Arte Útil in the Netherlands within the International Master of Artist Educator (iMAE) program at ArtEZ, University of the Arts in Arnhem (NL). At the end of the course, the students sent us unsolicited feedback about the programme emphasising how the principles of Arte Útil directly affected their perception of art and how it intersects with other social practices.

Approaching the school environment with the idea to co-create with the students rather than for them, has allowed us to encourage and compare various possibilities of using the archive within an academic framework and to consider how this could become a form of curating. Through a dialogic form, the archive was integrated as a pedagogical device, encouraging students to use the online platform for learning and research purposes, and they were encouraged to visit current projects according to their interests. We sought to stimulate the investigation of these practices, in particular those focused on the content delivered by the iMAE. For example, we included artists that are operating in the fields of radical pedagogy, immigration, and housing rights in The Netherlands, and the revealing of hidden warfare systems, in particular, in the city of The Hague, to name just a few. In addition, students could hear from different individuals-including artists and project initiators directly involved in the Arte Útil movement-about the strategies put in place to develop their projects. For example, Figure 3 shows students during a studio visit to artist Kevin van Braak in Arnhem, which became a culinary performance outside his studio. Students helped van Braak activate the artwork Bus (The Good Life), cooking fried rice that was shared while discussing some aspects of his work. The activation of the artwork was unplanned at the outset; however, it was the best way to understand the nature of van Braak's practice that uses food as a vehicle for storytelling through a direct experience.

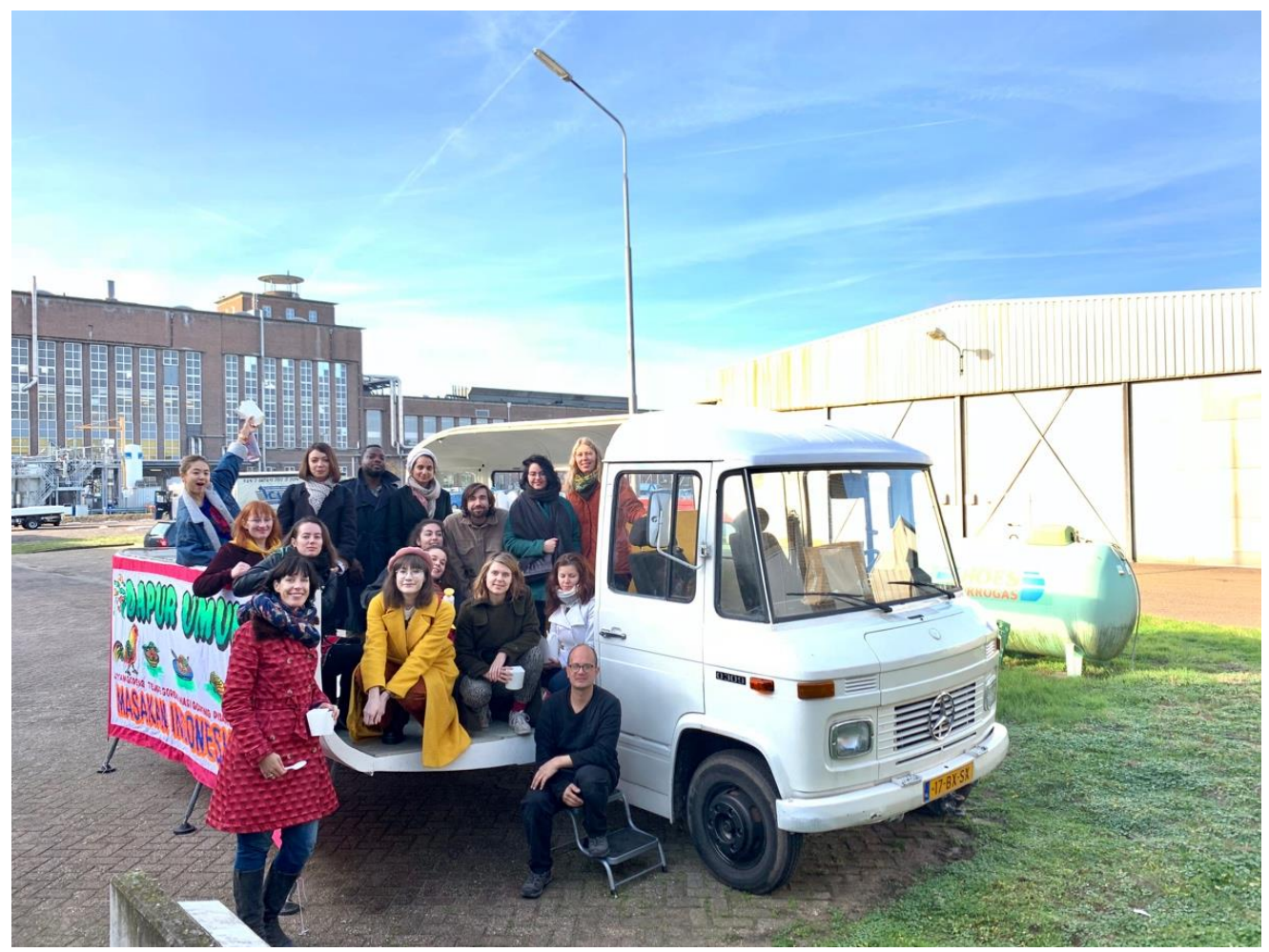

Figure 3. iMAE students during a studio visit with artist Kevin van Braak, Arnhem, NL. 
The syllabus has been evolving every academic year, responding to the urgency of the moment. At the same time, it addresses general questions around socially engaged practices, in particular the impact of artistic research on the lives of those involved in the projects. Over the course of four semesters, we discussed topics that included: modes of production, processes of collaboration, authorship and power dynamics, collective pedagogy, economies of exchange, artistic strategies, ethics, instrumentalisation, use and misuse, the lexicon of usership, the impossibility of the canon, the autonomy of art, the position of the spectator, the construction of history, and so on.

In this case, when the Arte Util archive infiltrated the classroom, rubbing alongside the modern narratives of art and artistic practice, it triggered a series of debates that fosters a critical learning ecosystem linking theory and practice. The archive became an educational tool creating multiple constellations of projects that act as catalysts for discussing local issues and international struggles, whilst at the same time provoking dialogue and analysis around the notion of art and the modern paradigm. The most immediate feedback from the cohort could be seen in students' additions to the curriculum. They brought up relevant issues linked to their different backgrounds, geographical contexts, or research interests. Reflecting on that, the students generally expressed that the array of materials, case studies, themes, and subjects presented in class helped them to critically analyse the subject of their study. Another aspect worth mentioning is the use of the Arte Util criteria together with the key words included in Toward a Lexicon of Usership (Wright 2013). Both the criteria and some specific words were instrumental for reflecting upon characteristics and contradictions of the practice. Furthermore, in order to merge the speculative approach with the practical one, the programme included theoretical exercises, workshops, embodied activities, and tools that activate some of the concepts discussed during the sessions such as the "Coefficient of Art". The latter exercise in particular helped the comprehension of a fundamental principle in both a practical and physical manner. For it, students were encouraged to think about the "amount of art" in their practice, how it evolves and relates to other disciplines. This link between their projects with other fields helps to shift the reflection from what should be perceived as art to rather trying to define what art means with respect to their work.

Another device that was proposed to the cohort of students was the "Asociación de Arte Útil Mapping Tool". The tool consists of a tea and coffee table set which includes different color-coded stickers representing value chains, connections, and relationships between the individuals and institutions that are members of the Asociación. Its initial purpose was to be used as a tactic to map the different economic relationships between the project and its stakeholders, while having a tea or a coffee amongst the participants of the meeting. When it was adapted to the iMAE course, it was used by the students to map their own group and reveal points of encounters and divergences. The adaptation of the mapping tool became relevant as it was understood as a way to reveal some power dynamics within the group in the initial phase of the study.

One student talking about the "Coefficient of Art" exercise concluded:

"I could proudly say that after being exposed to Arte Útil I do feel more comfortable with the positions/multiple roles I have played in the creation of projects. Let's say that my coefficient of art now is more $75-25$ vs. 50-50. In other words, you have helped me to see the value I bring."

The above feedback is a good example that helps us to illustrate how we designed the course. We wanted to bring students closer to the actual practice and the networks, organizations, and institutional structures connected to these practices in The Netherlands. To do so we invited guest speakers and we visited projects' locations, exhibitions, and archives that were complementary to the time spent in class. In practical terms, it seemed that this nexus with the "outside" world was the university's most challenging endeavour. Despite the fact that the vision of iMAE explicitly refers to experiential learning strategies (Kolb 1984), it took a long time to the students before becoming accustomed to a rhizomatic teaching and learning approach proposed by the teachers. As an attempt to fill the gap between the school's class and what happened outside of it, we invited seven artists and 
collectives as mentors for a practice-based training. Students had the chance to work with artists Libia Castro and Ólafur Ólafsson, based between Rotterdam and Reykjavik; Rebeca Gomperts, initiator of Women on Waves, based in Amsterdam; project Freehouse in Rotterdam; Kevin van Braak, based in Arnhem; Hans Kalliwoda, initiator of the project BeeCare Amsterdam, Foundation We are in Eindhoven; and Gluklya, based in Amsterdam.

Over the course of two months, they welcomed the students as members of their workshops, studios, or projects, sharing their work habits and guiding them with their own research projects and final presentations. The cohort convened its experiences with each other on a weekly basis. This process confronted the students with the discrepancy between the tempo and praxis of socially engaged art practices versus the one of the school projects. On the one hand, this structure highlighted the potentiality of the university to be a relatively "safe space" for students to experiment before "going out into the world". On the other, it revealed the constraints that exist within the given conventional structures and expectations of the university. As it was problematised by one student regarding a visit to a museum, institutional protocols, schemes, and settings of control are not easily overcome with collective authorship:

"The only thing that I would like to understand more is why in Eindhoven we didn't "use" the facilities of the museum and we spent most of the time sit (sic) in the same place. I heard from somebody that a museum tour was scheduled, but then, the schedule changed. In the future I would like, if it's possible, to have an introduction of the schedule and if there is a doubt about the organization please give the students the choice of which activity they would prefer to do. (Collective Authorship!)"

As highlighted by the previous comment, there were some initial complaints about the amount of time spent outside of the school, in particular regarding the inconveniences of travelling across different cities, and the unusual—or lack of—structure of the lessons. As noted by another student during a particularly quiet lesson, when we asked the room for some mid-term evaluation:

"You should understand that for us it is difficult (co-creating with our teachers) because we have been taught all our lives that for being 'good students' we just have to listen".

Hence it was clear that our method was not perceived and recognised either as curatorial or educational. Despite the fact that Arte Util as an educational methodology is indebted to some well-known figures who operate in the framework of critical (Freire 2018) and feminist (Hooks 2014) pedagogy, and other methods elaborated by socially engaged art practitioners discussed by other teachers (Helguera 2010; Bruguera 2002; García Canclini 2019; Godínez Nivón 2010; Castelblanco 2011), we felt we made an assumption that led students to feel frustrated.

However, in later feedback, they agreed that starting from the perspective of the flaneur ${ }^{12}$ brought them back to a sense of wonder, as if they were on a primary school trip, recovering the quality from being open and genuinely interested in listening and learning. They appreciated and emphasised our effort to apply a methodology close to the notion of Arte Útil and social practice together with them. Collaboration, a sense of care, horizontal dialogue, and communication were some aspects that students appreciated the most.

Regardless of the favourable feedback and the openness of iMAE's programme leader that has allowed us to develop an unorthodox approach to education, we cannot deny the intricate position and difficulties of our practice. The first aspect worth mentioning regards the fragility of our position as external lecturers within the structure of the university. Fostering co-creation and shared authorship with the students while working inside an institution such as the university - traditionally defined by a fixed and codified set of behavioural rules - entailed a certain kind of shift within our way of working. It implied the need for more time and space for unlearning and exchange from both sides. At the 
time of this writing, after a radical set of funding cuts together with restrictions due to the COVID-19 pandemic, our course has been drastically reduced to a two-day seminar.

\section{Conclusions}

Applied to these two cases, Rogoff's notion of "education as a site for curiosity rather than identity", has helped us to highlight how stressing the pedagogical aspect of the archive furthered its function as a generative platform rather than a mere repository of information.

In particular, reiterating the educational aspect of the curatorial process became the turning point for the archive to be used as a tool in and of itself. Curatorial and artistic research in this case lays the basis for the conception of a toolkit that allowed for the means of research (in our case the archiving practice) to develop in parallel with its own content (Bouteloup 2020).

According to the principle of Arte Útil discussed earlier, the practice of opening the programming process to collective authorship revealed how case studies informed our work. Precisely because Arte Útil suggests "an operational mode that begins implementation before all the details of a plan have been settled" (Bertand 2019), we can argue that co-creating with others allowed a collective experimentation that affected several realms. Moreover, in both cases discussed earlier, the archive became a way to infiltrate and question working protocols within both art and educational institutions.

As a result, we understood the possibility of the archive to become a porous mechanism thanks to the fact that it is both the result and the tool for research. Using the archive freely and adapting the selection of case studies according to the urgency of the moment, potentially enabled anyone to activate a curatorial process intended as a collective action. In this way, users (those being students, artists, social workers, or visitors) co-curated the sessions with us, adding discussion points and reflections on the distinction and overlaps between socially engaged art practices and other fields at a local and global scale.

Yet, many criticalities emerged from this process. Despite the criteria being conceived and understood by some as the key to access the conceptual framework of the archive, its uses vary depending on the context that informs the discussion. As extensively described, the criteria serve both as a practical and conceptual reference for Arte Útil to be recognized as a new category in the arts. Any act of labelling, classifying, and framing implies a constraint, but it also gives the possibility to name, to study, and to give visibility to something in its totality. As it was pointed out by those who used the Office of Useful Art at SALT and those involved in Agents of Change, it was not clear why they need to label their projects as art, nor, consequently, the value of being included in the archive. In both cases in fact, it seemed more useful to talk about Arte Útil as a methodology rather than as an art movement.

At the outset of this article, we asked if curating as a social practice could expand the notion of education. In facing this question, as Marina Garcés contemplates, it might be useful to interrogate our position in relation to the notion of education itself. "Is learning just a fairly sophisticated mechanism of survival or competence? Or is it a fundamental practice of creating and transforming ourselves?" (Garcés 2020, p. 15). After considering the case studies of the Office of Useful at SALT and our collaboration with iMAE at ArtEZ, we could conclude that curating and teaching using the Arte Útil archive has enabled a process of self-reflection. It has created the conditions for imagining how these institutions could function differently, as in the case of creating such projects discussed earlier as Researchers at $S A L T$ and in including the principles of Arte Util at the core of iMAE curriculum. However, using the archive pushed us to acknowledge the challenges and contradictions that a social art practice introduces into such institutional structures, tempo, and functionality. On the other hand, it has delineated how curatorial, educational, and socially engaged art practices converge in a long-term process of collective learning.

Curating and teaching following the criteria of Arte Útil has helped us to merge thinking and practice as praxis. Project after project, we tried to understand what it means 
for us to be 'curating' and 'teaching' together with others and its impact on both the art context and beyond. Merging the curatorial with the pedagogical helped us to articulate our position before the archive and to clarify our specific usership with respect to it. Our 'pedagogy' then becomes the centre of our curatorial process in a manner articulated by Jaqui Alexander:

"Thus I came to understand pedagogies [... ] as in breaking through, transgressing, disrupting, displacing, inverting inherited concepts and practices, those psychic, analytic, and organisational methodologies we deploy to know what we believe we know so as to make different conversations and solidarities possible". (Alexander 2005, p. 7)

Author Contributions: Conceptualization, A.S. and G.M.E.; methodology, A.S. and G.M.E.; writingoriginal draft preparation, A.S. and G.M.E.; writing - review and editing, A.S. and G.M.E. All authors have read and agreed to the published version of the manuscript.

Funding: This research received no external funding.

Institutional Review Board Statement: The study was conducted in accordance with the Declaration of Helsinki, and approved by the Ethics Committee of Liverpool John Moores University (Minimal Risk UREC reference number 21/LSA/016 on 10 July 2021).

Informed Consent Statement: Informed consent was obtained from all subjects involved in the study.

Data Availability Statement: Not applicable.

Conflicts of Interest: The authors declare no conflict of interest.

\section{Notes}

1 The initial list of correspondents is available on https://museumarteutil.net/archive/ (accessed on 2 December 2021): Rael Artel, Claire Bishop, Clare Butcher, Binna Choi, Teddy Cruz, Ekaterina Degot, Galit Eilat, Tom van Gestel, Grizedale Arts, Claire Hsu, Abdellah Karroum, Grant Kester, Heejin Kim, Michy Marxuach, Cuauhtémoc Medina, Gabi Ngcobo, Paul O’Neill, Sarah Rifky, Caterina Riva, Lucía Sanromán, David Teh, Nato Thompson, Vivian Ziherl, Magdalena Ziolkowska.

2 The criteria used in this article represent a revised version that has been adopted since 2015. The first version was used to gather the case studies for the first presentation of the archive as part of the exhibition 'The Museum of Arte Útil' at the Van Abbemuseum and they are available at https://museumarteutil.net/about/ (accessed on 15 November 2021).

3 With the term para-institution we intend those projects that radically experiment with institutional models through self-reflexive interaction with the institutional format (Lütticken 2015).

4 New Institutionalism refers to a series of curatorial, educational and governance practices that from the mid-1990s and early 2000s championed alternative methods to operate within museums and contemporary art institutions to engage with societal issues and local communities. It exceeds the modern notion of the museum and the exhibition as its sole mechanism to foster other activities and dynamic processes, considering the galleries as a space for social inclusion and community building (Kolb and Flückiger 2013).

5 All the activities and the publication are available on https:// broadcastingthearchive.tumblr.com/ (accessed on 7 December 2021).

6 Currently formed by partner institutions: MG+MSUM (Ljubljana), Museo Reina Sofía (Madrid), MACBA (Barcelona), M HKA (Antwerp), SALT (Istanbul \& Ankara), Van Abbemuseum (Eindhoven), MSN (Warsaw)/NCAD (Dublin), HDK-Valand (Gothenburg). More information available on https://www.internationaleonline.org/ (accessed on 7 December 2021).

7 The umbrella Network is a collective of researchers, artists and designers based in Eindhoven formed by: Ron Krielen, Christine van Meegen, Gemma Medina, Minsung Wang, Conor Travinsky, Daisy O'neill and Sebastian Kubersky. More information about the project and the publication is available on https:/ / theumbrella.nl/agentsofchange/ (accessed on 7 December 2021).

8 Agents of Change articulated an introductory research that supported different stages of the three years program: the Werksalon. https://vanabbemuseum.nl/en/programme/programme/werksalon/ (accessed on 7 December 2021).

9 We refer to sustainability in the sense of time and engagement of the people-institutions involved. In other words, we ponder the necessary conditions to foster long-term processes based on ecologies of collaboration.

10 In the following interview Tania Bruguera explains why Arte Útil has been identified as a movement rather than a project. The interview, recorded at the Van Abbemuseum on the occasion of the Museum of Arte Útil, was conducted by Nick Aikens, who was part of the curatorial team of the exhibition. It is available on https://www.youtube.com/watch?v=Xs5EJmt19K4 (accessed on 13 January 2022). 
11 SALT is a cultural institution in Turkey that provides a constellation of programmes such as research-based exhibitions, publications, web and digitization projects, conferences, workshops and screenings. It focuses on art, architecture, design, and social and economic histories. The programmes are distributed between SALT Beyoğlu, SALT Galata (both in Istanbul) and SALT Ankara. As part of its mission SALT offers a context for debate and co-learning with its users being artists, curators, students, researchers and other constituencies. The Office of Arte Útil at SALT Galata was conceived in order to address some challenges that museums and art institutions are currently facing, for example how to expand the potential of co-learning with their users and responding to the necessities of the present. Therefore, the programme of The Office of Arte Util was specifically co-created with their users, over a relatively long span of time, such as two years, and without any prefigured outcome. In fact, one of the programme that has been a consequence of the Office was 'Researchers as SALT' a user-generated series of talks and presentations that explored works created by using publications, online archive collections and the facilities provided by the institution.

12 A flaneur is someone who strolls around without any direction but watching people and society as an observer of life in the modern city. The term comes from the French masculine noun "flâneur" meaning "stroller" and it was described at length by Charles Baudelaire [1863] (1964) in the poem: The Painter of Modern Life.

\section{References}

Alexander, M. Jaqui. 2005. Pedagogies of Crossing: Meditations on Feminism, Sexual Politics, Memory, and the Sacred. London and Durham: Duke University Press, p. 7.

Anand, Shaina. 2016. 10 Thesis on the Archive. In Autonomous Archiving, 1st ed. Edited by Artikişler Collective. Barcelona: DPR, pp. 79-96.

Baudelaire, Charles. 1964. The Painter of Modern Life. New York: Da Capo Press. First published 1863.

Bertand, Stéphanie. 2019. Useful Curating. Limerick: Ormston House.

Bouteloup, Mélanie. 2020. Autohistoria as praxis. In Institution as Praxis. New Curatorial Directions for Collaborative Research, 1st ed. Edited by Carolina Rito and Bill Balaskas. Berlin: Sternberg Press, pp. 156-69.

Bruguera, Tania. 2002. Cátedra Arte de Conducta. Available online: http://www.taniabruguera.com/cms/492-0-Ctedra+Arte+de+ Conducta+Behavior+Art+School.htm (accessed on 7 December 2021).

Castelblanco, Felipe. 2011. The Para-Site School. Available online: https:/ / parasiteschool.org/ (accessed on 4 December 2021).

Danto, Arthur Coleman. 1997. After the End of Art: Contemporary Art and the Pale of History. Princeton: Princeton University Press.

Doherty, Claire. 2004. The institution is dead! Long live the institution! Contemporary Art and New Institutionalism. Engage Review Art of Encounter 15: 6, Summer. Available online: https://engage.org/wp-content/uploads/2019/03/Engage15_ClaireDoherty_ Theinstitutionisdead.pdf (accessed on 2 December 2021).

Dorner, Alexander. 1958. The Way beyond 'Art', revised ed. New York: New York University Press.

Freire, Paulo. 2018. Pedagogy of the Oppressed, 50th Anniversary ed. London: Bloomsbury Publishing.

Garcés, Marina. 2020. Escuela de Aprendices. Barcelona: Galaxia Gutenberg.

García Canclini, Nestor. 2019. Tequiografías: Reimaginating Interculturality. Visible Project [blog]. Available online: https://www. visibleproject.org/blog/text/tequiografias-reimaginating-interculturality/ (accessed on 3 December 2021).

Godínez Nivón, Daniel. 2010. Tequiografías. Available online: https:/ /www.danielgodineznivon.com/Tequiografias (accessed on 4 December 2021).

Helguera, Pablo. 2010. Notes toward a Transpedagogy. In Art, Architecture and Pedagogy: Experiments in Learning, 1st ed. Edited by Ken Ehrlich. Los Angeles: Viralnet.net, Available online: https:/ /www.blurb.com/books/1347259-art-architecture-pedagogy (accessed on 13 September 2021).

Hooks, Bell. 2014. Teaching to Transgress. London: Routledge.

Kolb, David Allen. 1984. Experiential Learning: Experience As The Source of Learning And Development. Englewood Cliffs: Prentice Hall.

Kolb, Lucie, and Gabriel Flückiger. 2013. New Institutionalism Revisited. In OnCurating Issue 21. Available online: https:/ /www.oncurating.org/issue-21.html\#. YeklIVhKhE4 (accessed on 4 December 2021).

Lütticken, Sven. 2015. Social media: Practices of (in) visibility in Contemporary Art. Afterall: A Journal of Art, Context and Enquiry 40: 4-19. [CrossRef]

Medina, Gemma, and Alessandra Saviotti. 2019. Toolkit for institutions. In Broadcasting the Archive, the Publication. Cork: Cork Printmakers.

Martinon, Jean-Paul, and Irit Rogoff. 2013. Preface. In The Curatorial: A Philosophy of Curating, 1st ed. Edited by Jean-Paul Martinon. London: Bloomsbury.

Rito, Carolina, and Bill Balaskas. 2020. Institution as Praxis. New Curatorial Directions for Collaborative Research. Berlin: Sternberg Press.

Rogoff, Irit. 2008. Turning. E-flux Journal, 6. Available online: https://www.e-flux.com/journal/00/68470/turning/ (accessed on 7 December 2021).

Ruskin, John. 1870. The relation of Art and Use. In Lectures on Art. Oxford: Clarendon Press.

SALT. 2017. Office of Useful Art. Available online: https://saltonline.org/en/1667/office-of-useful-art?q=Arte+\%C3\%9Atil (accessed on 25 November 2021).

Seven, Aslı. 2018. Uses and Misuses of Arte Útil: The Archive, the Conversations and the Institutional Scale. Available online: https:/ / saltonline.org/en/1880/uses-and-misuses-of-arte-util-the-archive-the-conversations-and-the-institutional-scale? $\mathrm{q}=$ Arte $+\%$ C3\%9Atil (accessed on 1 December 2021). 
Steadman, Alec. 2016. Notes from the Field: Re-articulating the role of aesthetics in relation to functionality. Available online: https:/ / www.arte-util.org/notes-from-the-field-re-articulating-the-role-of-aesthetics-in-relation-to-functionality/ (accessed on 16 September 2021).

Wright, Stephen. 2013. Toward a Lexicon of Usership. Eindhoven: Van Abbemuseum.

Yıldız, Onur, and Naz Kocadere. 2018. The Usological Turn: An Interview with Stephen Wright. Available online: https://blog. saltonline.org/post/173507131854/the-usological-turn-an-interview-with-stephen (accessed on 1 December 2021). 